\title{
The Role of Companies in Human Capital Accumulation: A Cross-Country Analysis
}

\author{
Natalia Bondarenko
}

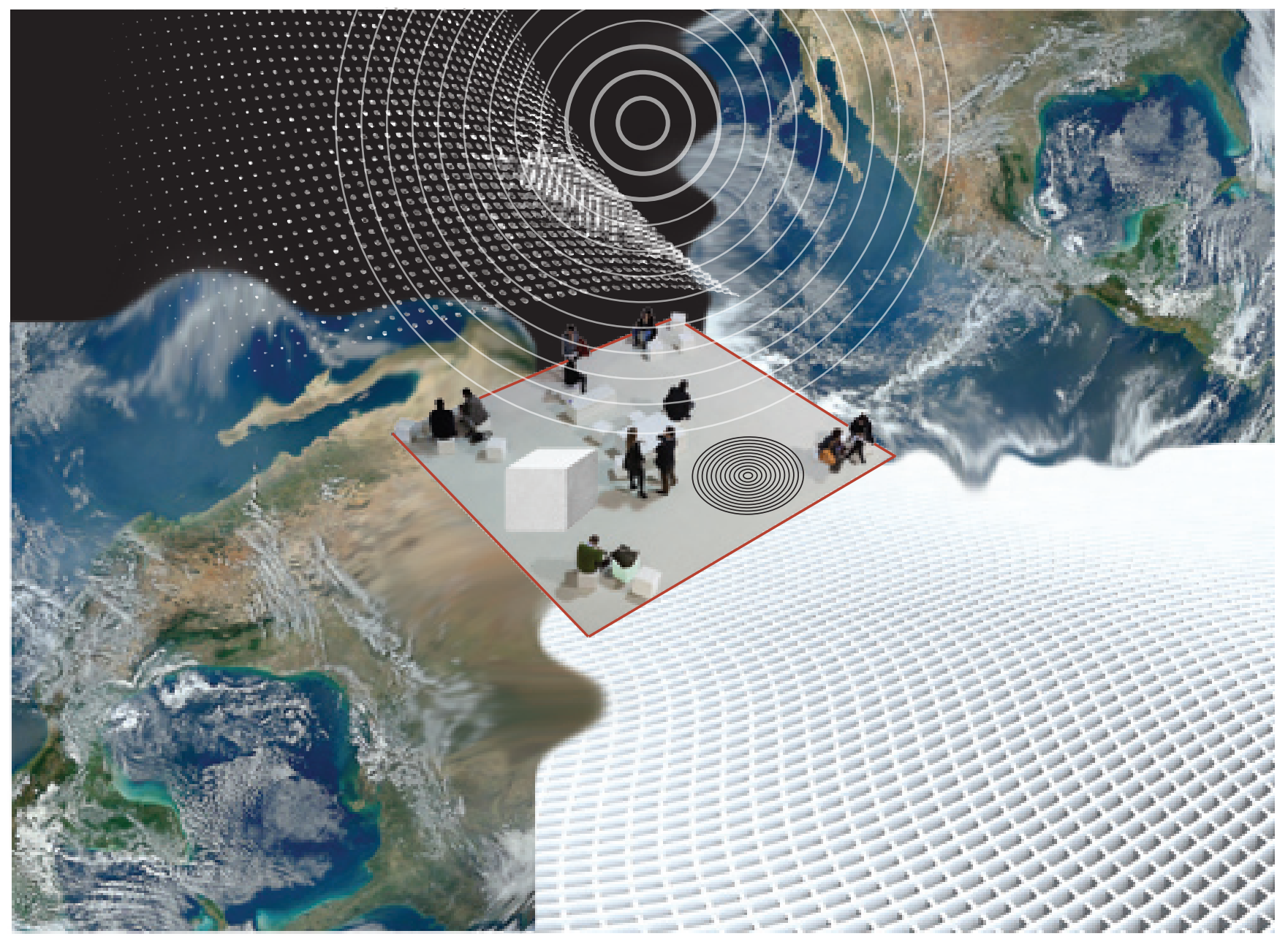

The development of human capital in forms in which it accumulates can be effectively investigated through a case study of the participation of the adult economically active adult population in lifelong learning. This study is devoted to assessing the involvement of managers and employees at Russian companies in lifelong learning and the role of Russian firms in organizing this type of education compared with practices in the European Union (EU) and the OECD. The paper is based on a comparative analysis of international sociological surveys and a survey of Russian employers in six sectors of economy, conducted by National research Research university University HSE and the Levada Center as a part of project 'Monitoring of Education Markets and Organizations', with the support of the Russian Ministry of Education and Science.
Natalia Bondarenko - Leading Research Fellow

Levada Analytical Center (Levada Center)

Address: 17 Nikolskaya str., 109012 Moscow, Russian Federation

E-mail: nut@levada.ru

\section{Keywords}

human capital; top-managers of companies; lifelong learning; formal training of adult population; higher education; inequality in education and training; professional skills; innovation activity of companies

DOI: 10.17323/1995-459X.2015.2.22.37 
A comprehensive evaluation of the innovative potential and efficiency of the economies of certain countries on a macro level involves key indicators of human capital quality [Healy et al., 2011]. Added to these, along with the average duration of training and the proportion of the economically active population (aged from 25 to 64 years) with a higher education, researchers of ten look at the number of participants in lifelong learning programmes. This is because individual capabilities and talents, educational capital accumulated through formal training, and skills and competencies acquired in life, including through a professional career, are the basic elements of human capital.

On a micro level, quality labour resources serve as a guarantee for employers of a company's effective current operations, opportunities to implement new projects, to introduce and adapt innovative products, technologies, etc. Certain micro-studies, including several Russian and regional studies, have corroborated the hypothesis that participants in lifelong learning programmes who are regularly raising their skill sets tend more frequently to show high levels of interest in innovation, a readiness to establish new firms and to develop and launch new goods onto the market, to implement new technologies, etc. [BIS, 2010; Verdonschot, 2012; Gokhberg, Poliakova, 2014; Trubin, 2011].

In OECD countries, the problem of differentiating human capital attracts the utmost attention from specialists. A number of studies have been dedicated to identifying key factors and assessing the extent of educational inequality, its impact on economic growth and the effectiveness of measures to reduce inequality [European Commission, 2014, pp. 23-28; OECD, 2014, pp. 49-50]. Researchers in the EU have confirmed that differences in human capital indicators turn out to be more significant not so much between national economies, but between socio-demographic groups within national economies (in particular, between groups whose parents had lower cultural, economic or social status and those whose parents had higher positions in the social stratification) [Blanden, $\mathrm{Mc}^{-}$ Nally, 2015, pp. 16, 20-21; European Commission, 2014, p. 25]. Sustaining stable economic growth cannot be simply reduced to ensuring that human capital indicators remain positive (for example, the proportion of those with a higher education); it also requires a reduction in educational inequality by improving the professional and qualification status of some of the poorest groups of the population. Attention has been paid to these groups as a matter of priority as a result of statistical calculations showing that equal access for economically disadvantaged citizens to education and skills training results in smoothing over existing differences in labour productivity and the pay received [Blanden, McNally, 2015, pp. 27-28].

\section{Experience of lifelong learning studies}

What are the evaluations of human capital quality and the prospects of improving quality in Russia formed from? What impact does the level of involvement of certain groups of the economically active population in lifelong learning have? What is the extent of educational inequality in Russia? Which forms of lifelong learning are prevalent and what is the extent of involvement by employees, companies and the state in such programmes? The responses to these questions would be incomplete if they were only based on education and employment statistics. Data from sociological surveys, which have been developed intensively in certain countries ${ }^{2}$ and on an international level ${ }^{3}$, make it possible to significantly add to researchers' and experts' understanding of human capital accumulation and renewal. The results of such regular samples are used in administrative decision-making and by companies themselves, as well as by governments when developing balanced labour and education policies.

In Russia, as part of the 'Monitoring of Education Markets and Organizations' project, regular pan-Russian employer surveys have been carried out since 2005

\footnotetext{
Cf., for example, the employers' study on professional skills and know-how among workers in the United Kingdom: [Kik et al., 2014].

3 In particular, the European employers' survey on worker professional skills requirements [Cedefop, 2013], a study by companies on staff involvement in lifelong professional learning in companies [Eurostat, 2010], and a survey on the skilled worker shortage problem [Manpowergroup, 2014].
} 


\section{Fig. 1. Educational capital of workers and training in industry: international comparisons}

1. Companies that have been introducing new goods, services, technologies and organizational and marketing practices
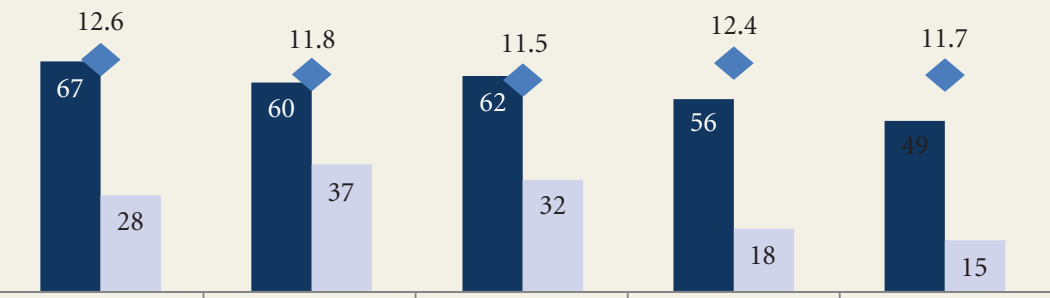

2. Companies that have not been introducing any innovations (new goods, services, technologies, etc.)

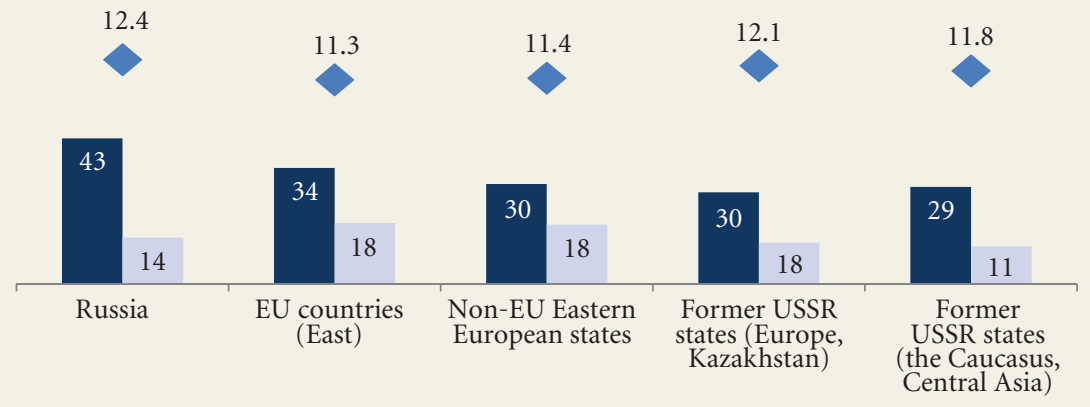

- Proportion of industrial companies providing organized training for employees (\%)

Proportion of trainees in the previous year in organized training programmes as a percentage of the total number of industrial company employees

- Average number of years' study by company employees

Source: data from the BEEPS survey for 2012-2013 [EBRD, 2014].

across six economic sectors ${ }^{4}$ [Krasilnikova et al., 2005, p. 56-57]. This article focuses mainly on comparing the results of the 'Monitoring of Education Markets and Organizations' project with data from similar surveys carried out in a number of OECD countries and in the EU, including surveys carried out by Eurostat on lifelong professional training for business employees (Continuing Vocational Training in Enterprises Survey, CVTS), adult education (Adult Education Survey) and the work force (Labour Force Survey). Another source is data from the international business environment and conduct survey carried out by the European Bank for Reconstruction and Development (EBRD) (Business Environment and Enterprise Performance Survey, BEEPS) [EBRD, 2014], which was also taken by Russian companies.

The BEEPS survey for 2012 and 2013 showed the leadership of the Russian labour market in terms of the level of formal professional education among workers (Fig. 1). In this regard, Russia exhibits some clear competitive advantages over EU member states, including the former Eastern Bloc. In particular, this means the higher average length of training for workers in industry with a higher education. Figures for post-Soviet Belarus, Ukraine and Kazakhstan are closer to Russian figures in this respect, which is attributable to them inheriting a common vocational education system. The proportion of workers with a higher education as a percentage of the total number employed in industry in Russia is more than 35\%, in former USSR states in Europe and Kazakhstan this figure is roughly 30\%, and in Eastern Europe, it is a little over 16\%. Other indicators of the state of the domestic labour market appear much worse against the global backdrop. For instance, the proportion of workers for whom Russian compa-

\footnotetext{
${ }^{4}$ Carried out by NRU HSE together with the Yuriy Levada Analytical Center (Levada Center), with support from the Russian Ministry of Education and Science. The aim of these employer surveys is to study their interest and willingness to play a role in the process of modernizing the professional education system, receive their views on the readiness of the qualified labour force to meet current and future business needs, and to analyze companies' needs for basic and continuous professional training for their staff. Available at: http:// memo.hse.ru/concept, accessed 24.03.2015.
} 
nies have been organizing training is less than the figures for EU countries. Even those Russian industrial enterprises which have been introducing new goods, services, technologies, work methods, forms of organization and product promotions still fall behind these countries.

International surveys of company managers, including those that are dedicated to continuous professional staff training [Eurostat. 2010] and the demand for qualified workers in the EU [Cedefop, 2013], point to the indisputable trend of the growing importance of universal conduct skills among staff (soft skills) alongside traditional core skills (hard skills). Accordingly, the demands that companies are making of their employees are changing: greater employee flexibility and adaptability and refusing to follow strict routine rules and procedures. The higher the vocational and professional status of an employee, the broader the range of universal skills are that are expected of that employee. According to data from the European Centre for the Development of Vocational Training (Cedefop), employers involved in innovation activity are the main drivers of demand for professional skill sets.

According to the results of a pilot survey of EU companies in 2012, regardless of an employee's specialization, employers forecast medium-term primary demand for universal skills: the ability to work in a team (essential for $90 \%$ of companies), the ability to learn ( $88 \%$ of companies), the ability to easily master new equipment and materials $(81 \%)$, independence in setting work objectives and choosing work methods and schedules $(81 \%)$, and the ability to convincingly defend a point of view (75\%) [Cedefop, 2013]. Thus, among the most soughtafter skills were those which required sustainable continuous training practices for validation and development.

In the Eurostat surveys devoted to continuous professional training, the growth in the proportion of companies (in particular, small and medium sized) involved in such programmes annually was 20-30\%, relative to 1993 levels [De Broeck, 2008, p. 5]. The comparison of figures for the mid-1990s and 2014 as part of the Labour Force Survey also recorded a steady increase in the proportion of the EU population aged 25-64 involved in continuous education (Fig. 2). The level and rate of growth in this figure differs from country to country: those most actively involved in lifelong learning are the Scandinavians, and the least are those from southern Europe.

An attempt to explore the nature of Russian companies' demands for universal and special professional skills among workers and to predict changes in these

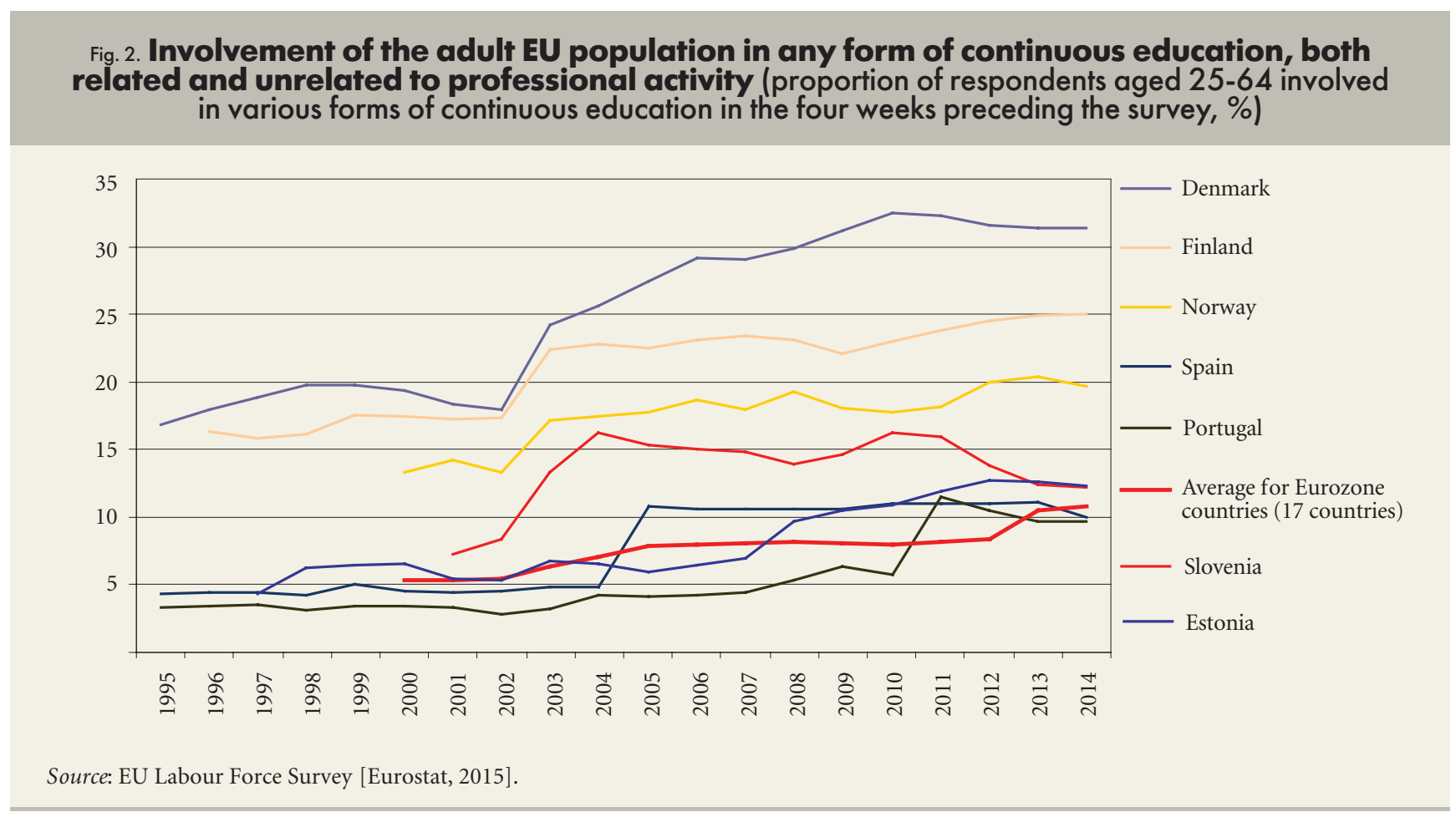


requirements over the next 2-3 years taking into account plans to modernize a business was made in our employer survey as part of the 'Monitoring of Education Markets and Organizations' project. The list includes the key skills mentioned in an equivalent British study [Kik et al., 2014] and CVTS survey [Eurostat, 2010]. This borrowing makes it possible to compare the specific features of the Russian and international labour markets revealed in the studies.

Roughly half of Russian employers surveyed under the 'Monitoring of Education Markets and Organizations' project in 2014 forecast changes in their requirements in terms of the professional skill sets of core worker categories. The differences in evaluations are down to the varying degrees of involvement of the companies in the innovation process (Table 1). Players which have adapted or developed new products, technologies, work methods, product promotion methods, etc. in the last 2-3 years or have planned to modernize in the near future are 2.5 times more likely (up to $55 \%$ of the companies in the group) to forecast such changes. It is not surprising that these companies are more likely to demand higher computer literacy, social and communication skills and ability to learn across all worker groups. Less routine work in an innovative organizational and technological environment requires independent decision-making skills, initiative and a customer orientation. Workers are also expected to exhibit traditional performance qualities: discipline, efficiency, and a responsible attitude toward set tasks.

According to current evaluations, employers faced with the problem of low worker qualifications, including scarce professional skills for all worker categories, mentioned universal behavioural skills as of ten as or more of ten than specialized (Table 2). Discipline and ability to learn are the most important for skilled workers (in roughly $40 \%$ of cases). With regard to specialists, in addition to the previously mentioned qualities, employers require increasing autonomy in decision-making (in almost $60 \%$ of cases) and the development of teamwork skills and customer interaction skills (in more than $40 \%$ of cases). For comparison, in roughly $40 \%$ of cases a lack of specialist knowledge among specialists was indicated.

The detailed breakdown of the data obtained through the manager surveys makes it possible to identify the demand of the management of different companies for particular skills depending on the administrative position of the respondent, his or her age, and even the extent of the innovative orientation of the company (Table 3). The results of the study confirm that the optimal form of developing (updating) sought-after professional qualities among workers is regular involvement in various lifelong learning programmes.

\begin{tabular}{|c|c|c|c|}
\hline & Specialists & $\begin{array}{c}\text { Skilled } \\
\text { workers }\end{array}$ & Professionals \\
\hline \multicolumn{4}{|l|}{ Core knowledge and skills (hard skills): } \\
\hline special professional knowledge, skills for work in the workplace & 17 & 20 & 13 \\
\hline basic computer literacy, knowledge of software & 28 & 13 & 20 \\
\hline general educational skills (reading, maths), general culture & 5 & 5 & 4 \\
\hline \multicolumn{4}{|l|}{ Universal conduct skills (soft skills): } \\
\hline ability to retrain, master new skills & 24 & 26 & 23 \\
\hline independent work-related decision-making skills & 22 & 13 & 13 \\
\hline customer skills & 14 & 7 & 12 \\
\hline teamwork, group skills & 11 & 7 & 10 \\
\hline time-management, work-management skills & 16 & 14 & 16 \\
\hline office administration skills & 6 & 3 & 7 \\
\hline discipline, efficiency & 12 & 22 & 10 \\
\hline desire/interest in working in the workplace & 8 & 16 & 9 \\
\hline
\end{tabular}

Source: data from the 'Monitoring of Education Markets and Organizations' 2014 employer survey. 
Table 2. Most scarce specialist and universal worker skills from an employer's perspective (proportion of respondents selecting the corresponding response as a percentage of the total number surveyed, \%)

Question to managers: 'What do workers with inadequate professional skills need above all else?'

\begin{tabular}{|c|c|c|c|}
\hline & Specialists & $\begin{array}{c}\text { Skilled } \\
\text { workers }\end{array}$ & Professionals \\
\hline \multicolumn{4}{|l|}{ Core knowledge and skills (hard skills): } \\
\hline special professional knowledge, skills for work in the workplace & 43 & 52 & 56 \\
\hline basic computer literacy, knowledge of software & 12 & 20 & 12 \\
\hline general educational skills (reading, maths), general culture & 29 & 24 & 18 \\
\hline \multicolumn{4}{|l|}{ Universal conduct skills (soft skills): } \\
\hline ability to retrain, master new skills & 42 & 34 & 27 \\
\hline independent work-related decision-making skills & 59 & 28 & 32 \\
\hline customer skills & 41 & 21 & 18 \\
\hline teamwork, group skills & 11 & 19 & 3 \\
\hline time-management, work-management skills & 42 & 46 & 29 \\
\hline office administration skills & 40 & 26 & 39 \\
\hline discipline, efficiency & 29 & 46 & 40 \\
\hline desire/interest in working in the workplace & 25 & 35 & 20 \\
\hline
\end{tabular}

Source: data from the 'Monitoring of Education Markets and Organizations' 2013 employer survey [Krasilnikova, Bondarenko, 2014, p. 36].

\section{Managers' careers and education}

It is with good reason that that we selected managers as the respondents to the surveys giving the results used in this article: the dominant management model in Russian companies (including small and medium sized) is typically a rigid vertical structure in which the key role in managerial decision-making and policymaking rests with executives. Their will shapes which developmental areas of human capital will receive financial support, which organizations will become partners in staff training, and which training practices will be adopted. All of these decisions are not in the least bit dependent on the level of competence of the company's management, its focus on change and renewal, or their satisfaction with professional training for staff. Rather, the effectiveness of the firm's management as a whole depends on the qualifications of the managers. In the

\section{Table 3. Importance of particular professional skills among workers for various categories of managers (proportion of respondents selecting the corresponding response as a percentage of the total number surveyed, \%)}

Question to managers: "Select one of the variants to complete this sentence: 'As a minimum each month, it is necessary to..."

\begin{tabular}{|c|c|c|c|c|c|c|c|c|}
\hline & \multicolumn{2}{|c|}{$\begin{array}{l}\text { Learn something } \\
\text { new at work }\end{array}$} & \multicolumn{2}{|c|}{$\begin{array}{c}\text { Find out about } \\
\text { new developments } \\
\text { (products, technologies, } \\
\text { etc.) }\end{array}$} & \multicolumn{2}{|c|}{$\begin{array}{l}\text { Solve entirely new } \\
\text { problems requiring } \\
\text { a rapid response }\end{array}$} & \multicolumn{2}{|c|}{$\begin{array}{l}\text { Solve new more complex } \\
\text { problems (which require } \\
\text { more than half an hour to } \\
\text { complete) }\end{array}$} \\
\hline & Managers & Deputies & Managers & Deputies & Managers & Deputies & Managers & Deputies \\
\hline & 53 & 61 & 53 & 64 & 66 & 61 & 65 & 60 \\
\hline \multicolumn{9}{|c|}{ Depending on the age of the respondent } \\
\hline Up to 45 years & 55 & 63 & 59 & 62 & 76 & 56 & 73 & 56 \\
\hline Over 45 years & 52 & 59 & 50 & 66 & 61 & 66 & 61 & 65 \\
\hline \multicolumn{9}{|c|}{$\begin{array}{l}\text { Depending on the level of innovation of a company (involvement in the development/introduction of new products and } \\
\text { technologies, work methods, forms of organization, forms of product promotion, etc.) }\end{array}$} \\
\hline Pioneered / developed & 59 & 69 & 60 & 73 & 72 & 68 & 72 & 68 \\
\hline $\begin{array}{r}\text { Did not pioneer / } \\
\text { did not develop }\end{array}$ & 31 & 51 & 35 & 51 & 42 & 49 & 42 & 47 \\
\hline \multicolumn{9}{|c|}{ Depending on the size of the company } \\
\hline$<50$ people & 58 & 82 & 58 & 88 & 59 & 80 & 53 & 79 \\
\hline 50-249 people & 47 & 60 & 49 & 63 & 65 & 60 & 67 & 59 \\
\hline$>250$ people & 57 & 66 & 61 & 67 & 64 & 63 & 71 & 64 \\
\hline
\end{tabular}

Source: data from the 'Monitoring of Education Markets and Organizations' 2014 employer survey. 
Fig. 3. Importance of a higher education for the successful professional activity of company managers (proportion of respondents selecting the corresponding response as a percentage of the total number surveyed, \%)

Question to managers: "How useful were your studies at a university or training institute in terms of preparing you for your work / career?"

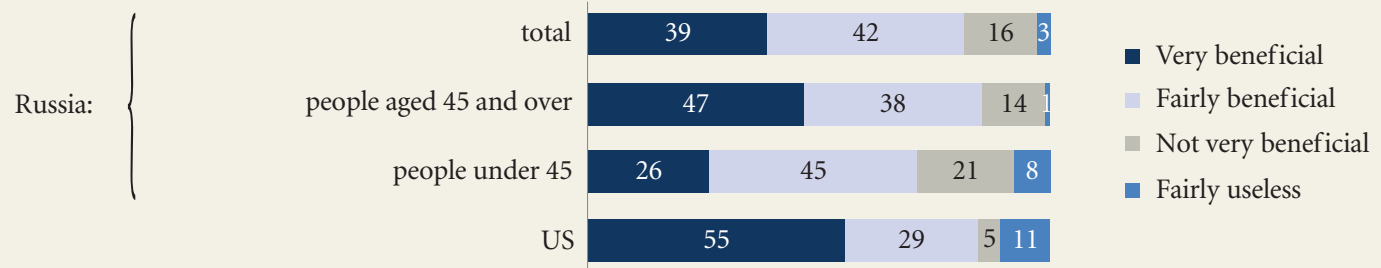

Sources: for Russia, data from the 'Monitoring of Education Markets and Organizations' employer survey for 2014; for the US, the Higher Education, Gender and Work Survey databases [PEW Research, 2013].

work [West et al., 1999], which uses hierarchical regression models on a case study of industrial companies, they recorded a statistically significant connection between the average level of education in a team of top managers (as the independent variable) and the efficiency of the business' operations, expressed in productivity and profitability.

As part of the 'Monitoring of Education Markets and Organizations' employer study, a group of senior (executives and deputies) and middle managers were surveyed (mostly heads of HR departments and finance and business divisions) (Fig. 3).

The vast majority of surveyed Russian managers considered their higher education to be rather useful, and among those who received their first professional education during the Soviet era, i.e. those respondents over 45 years of age, one in two indicated that their training was very useful to their future work. The managers among the post-Soviet graduates, i.e. those younger than 45 years of age, expressed similar opinions in half as many cases. The emerging generational gap can be explained by the declining quality of teaching in higher education in recent history as a result of teaching programmes falling behind demand from the external environment. Even in the 2005 'Monitoring of Education Markets and Organizations' survey, the most common view among company managers was that the period 1980-1990 was the decade with a higher level of professional training in Russian higher education institutions [Krasilnikova et al., 2005, p. 33]. The low level of satisfaction with the quality of education in terms of progressing the careers of managers is down to the focus of young managers on continuing their training without the traditional five-six year limitation. For comparison, university education satisfaction among American managers and businessmen, according to the results of the Higher Education, Gender and Work Survey [PEW Research, 2013], is relatively high: more than half of respondents considered their time spent in higher education productive in terms of their future profession.

According to the majority of surveyed managers of 45 years of age or more $(35 \%)$, they acquired their core knowledge and skills in formal training at a higher education institution (Fig. 4). Key to the professional development of younger managers, according to their own assessments, was informal training, in the form of self-education for $12 \%$ and during work (38\%). Moreover, Russian managers under the age of 45 mentioned informal ways of obtaining the skills they needed at work more frequently than their colleagues in the EU. For a large group of company managers in the EU (up to 15\%), further education was the main form of professional training. In Russia, where less than $5 \%$ of those surveyed selected this, further education plays an important role only in certain sectors, in particular in relation to innovation activity, where $15 \%$ of managers picked this option.

The survey of the management of Russian companies on the subjective needs for new knowledge, skills and higher overall qualifications in turn also shows a number of intergenerational differences (Fig. 5). It was more of ten younger managers (with more than half of those under 45 years of age) pointing to 
Figure 4. Importance of a higher education for the successful professional activity of company managers (proportion of respondents selecting the corresponding response as a percentage of the total number surveyed, \%)

Question to managers: "Select one of the variants to complete this sentence: 'The majority of the knowledge and skills that you use in your current job were mainly acquired as a result of..."”

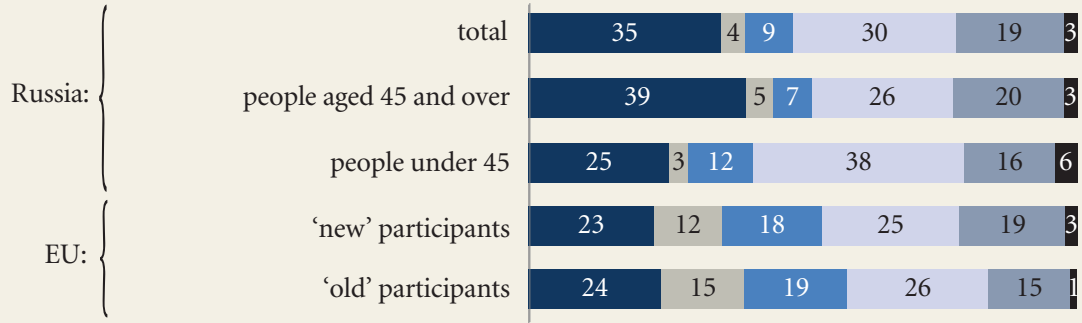

- receiving a core professional education (in a higher education institution, etc.)

v further training (in qualifications courses, etc.)

- independent training (without a mentor, teacher)

learning 'on the job', carrying out specific tasks

acquiring general life experience

- it is difficult to answer

Sources: for Russia, data from the 'Monitoring of Education Markets and Organizations' employer survey for 2014; for the EU, the Eurobarometer 62.1 databases [European Commission, 2004].

a lack of available professional knowledge. According to data from the Eurobarometer, the majority of managers in Eastern Europe feel that their acquired knowledge and skills are lacking in terms of their professional development [European Commission, 2004]. However, compared with their counterparts in the EU, clear ideas and plans to make up for the skills deficit are not unique to Russian senior and middle managers, which can be attributed to the lack of development of the Russian education services market for the economically active population over 25 years of age.

For managers of Russian companies that are known for their innovation activity or have plans to modernize their business in the near future, it is common to see increased interest in updating professional knowledge and skills (up to 55\%) and specific plans to make up for gaps in knowledge (up to 25\%). The bulk of those surveyed, irrespective of their managerial level, industry or age, mentioned

Figure 5. Satisfaction with the current level of professional training among company managers (proportion of respondents selecting the corresponding response as a percentage of the total number surveyed, \%)

Question to managers: “Select one of the variants to complete this sentence: 'For career development and professional, career growth...”'

\begin{tabular}{|c|c|c|c|c|}
\hline \multirow{3}{*}{ Russia: } & total & 52 & 12 & 32 \\
\hline & people aged 45 and over & 56 & 8 & 31 \\
\hline & people under 45 & 44 & 19 & 34 \\
\hline \multirow{2}{*}{ EU: } & 'new' participants & 46 & 31 & 17 \\
\hline & 'old' participants & 50 & & 12 \\
\hline
\end{tabular}

- your existing education and skills are currently perfectly sufficient

you need to undergo further specialist training / education, and intend to do so

- you need to undergo further specialist training / education, but cannot yet do so

it is hard to answer 
preferential learning during their life (Fig. 6). However, what is important is not so much involvement in lifelong learning, but actual use of learning in the activities of the respondent and the company as a whole in the lifelong learning process. The surveys show that interest in this form of support for professional skills is more of ten than not informal in nature, especially among young senior and middle managers. In the eyes of the older generations, the formal, status side of training continues to play an important role. According to the majority of managers, their involvement in lifelong learning brings benefits not only to them personally, but has an impact on the activities of the company as a whole (something that young managers are somewhat less convinced of, however). In companies that have engaged in innovation activities of various forms during the last 2-3 years, views on the benefits of lifelong learning are even stronger.

The highlighted intergenerational differences in motivations and preferences linked to learning must be taken into account when developing government measures to encourage company investment in employee training and the development of further education programmes. Managers on various levels have disagreed about who precisely should be responsible for organizing workers' continuous training (Fig. 6). Middle managers and young managers are more likely to hold the company itself responsible for this, while executives, on whom the financial figures of the business depend, expect more activity from the state.

According to the international definition [Eurostat, 2005; Gokhberg, 2012, pp. 175-177], lifelong learning (or, according to Eurostat's statistical reports, education, training and learning) covers all forms of educational activities, both formal and informal, aimed at refining knowledge, skills and abilities that are both related and unrelated to one's professional activity. The main types of lifelong learning are formal, additional (non-formal), informal and self education (informal learning). The proportion of the adult population participating in formal education (through a school, higher education, college or other vocational training institution) is low as, by the age of 25 , a basic education has, as a rule, already been achieved. Next, we will take a closer look at the activity of workers and company managers in further education - in the form of courses, lectures, seminars, one-off and regular training sessions, master classes, etc., i.e. non-core programmes - and informal education, including self-education - through studying literature, visiting exhibitions, libraries, taking open online courses, etc.

\section{Figure 6. Attitudes of Russian company managers towards training (proportion of respondents} selecting the corresponding response as a percentage of the total number surveyed, \%)*

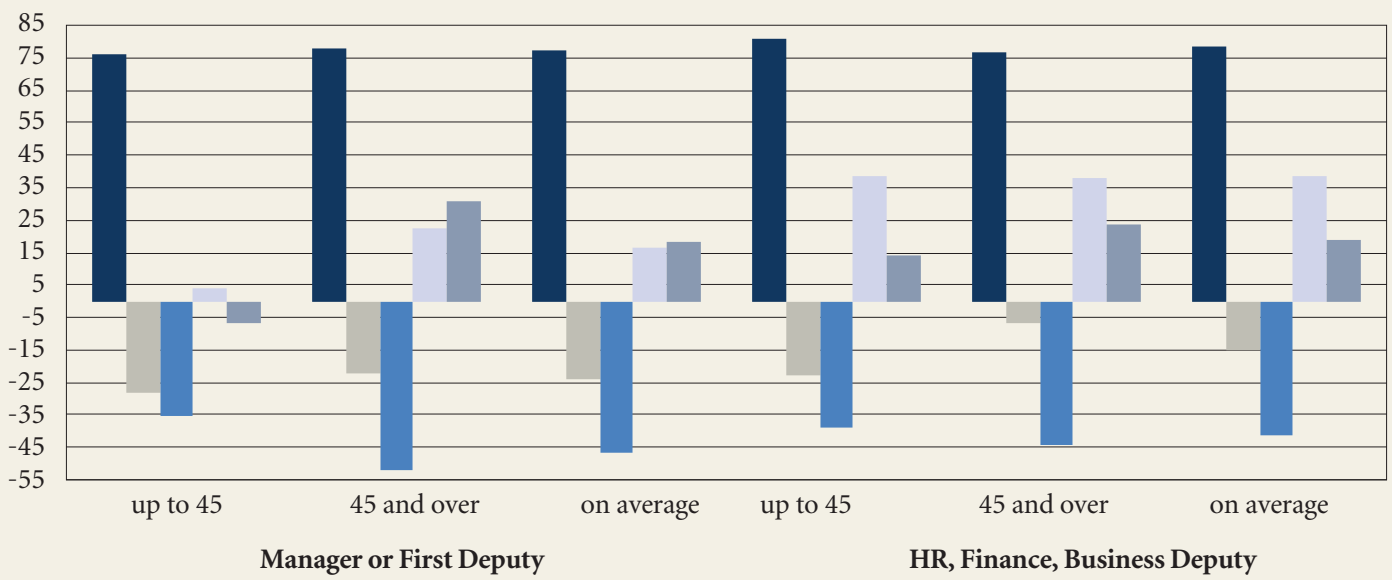

Training is something that has to be done throughout life

- Studies are worthwhile only if you get a diploma, certificate or other document confirming the qualification as a result

- My new skills will not be used at this place of work, in the company

In principle, employee training is the company's responsibility

The state should fund all forms of adult education

* Indices are provided for each judgement, calculated as the difference between the proportion of positive and negative responses in the range between 'agree - disagree'.

Source: data from the 'Monitoring of Education Markets and Organizations' 2014 employer survey. 


\section{Figure 7 . Involvement of company managers in lifelong learning in the four weeks before the survey (proportion of respondents selecting the corresponding response as a percentage of the total number surveyed, \%)}

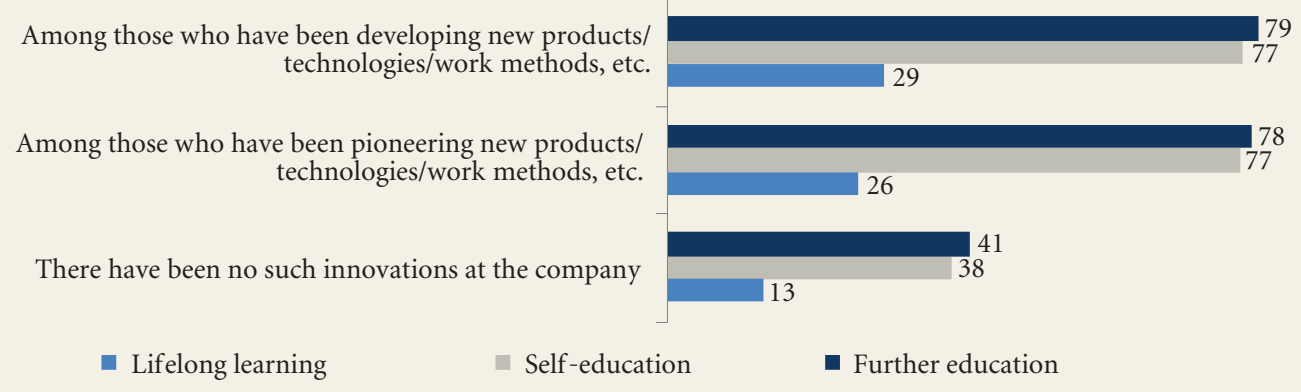

Source: data from the 'Monitoring of Education Markets and Organizations' 2014 employer survey.

The actual involvement of a manager in the various forms of lifelong learning is attributable to the nature of the company that he or she manages, its level of innovation and the size of the company. The survey results revealed that further education, both related and unrelated to the professional activity for an equal period of time, was received by almost twice as many managers of companies with over 250 workers (up to $37 \%$ ) compared with those whose employee numbers are lower. The management personnel of large companies are less willing to engage in self-education.

We have already noted that the higher the demand for lifelong learning among managers, the greater the extent of the modernization and innovation activities at the company. Managers of companies that have been developing or introducing new products, technologies, work methods, forms of organization, etc. over the last 2-3 years are twice as likely to participate in lifelong learning compared with their counterparts involved in more traditional forms of activity (Fig. 7).

The age of management also affects education activity. An analysis shows that the inter-industry differences are virtually smoothed over in the group of managers aged younger than 45 years (Fig. 8). Members of this specific age cohort are more active than others in terms of updating and increasing their professional knowledge and skills.

\section{Figure 8. Involvement of company managers in lifelong learning in the four weeks before the survey (proportion of respondents selecting the corresponding response as a percentage of the total number surveyed, \%)}

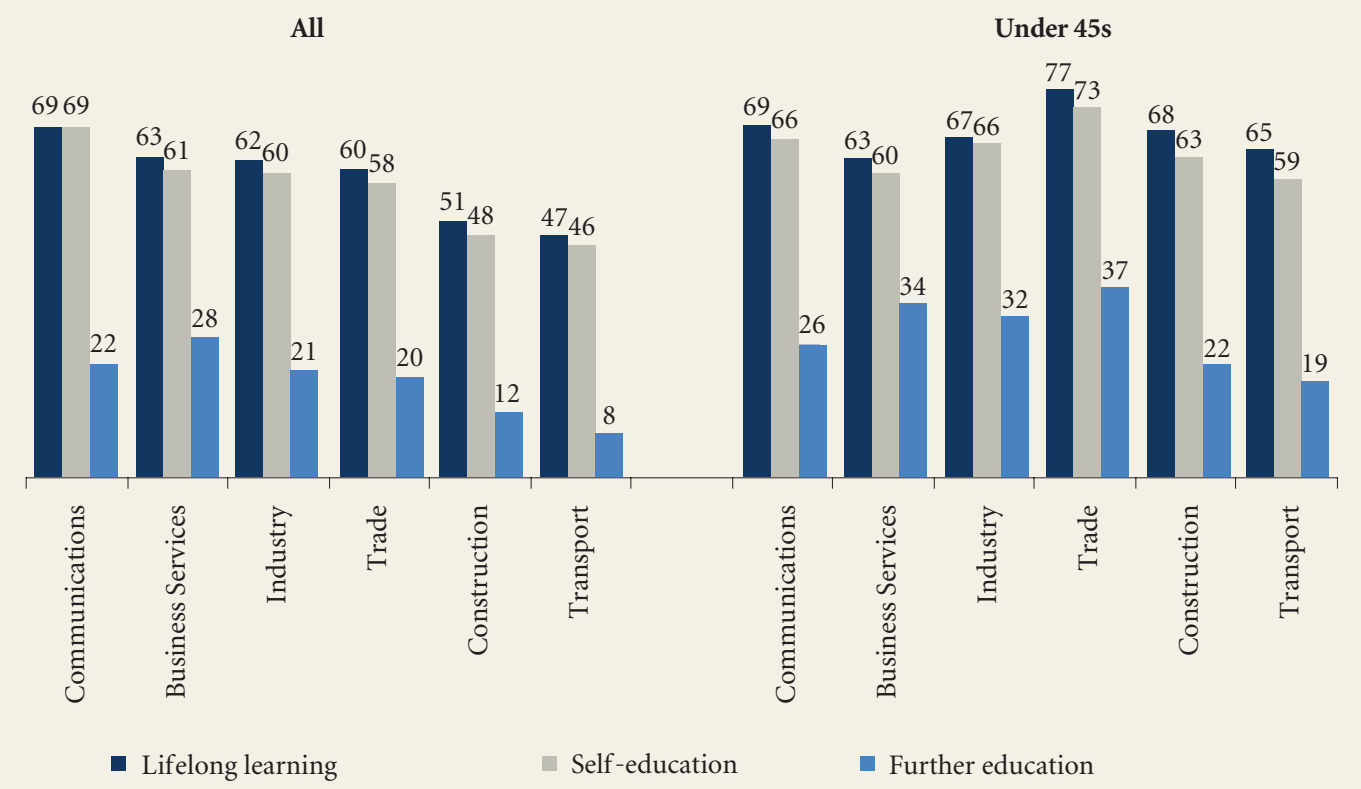

Source: data from the 'Monitoring of Education Markets and Organizations' 2014 employer survey. 
Fig. 9. Regularity of company managers' involvement in additional training programmes

(proportion of respondents selecting the corresponding response as a percentage of the total number surveyed, \%)

Question to managers: 'In which year was the last time that you underwent additional training related to your professional activity?'

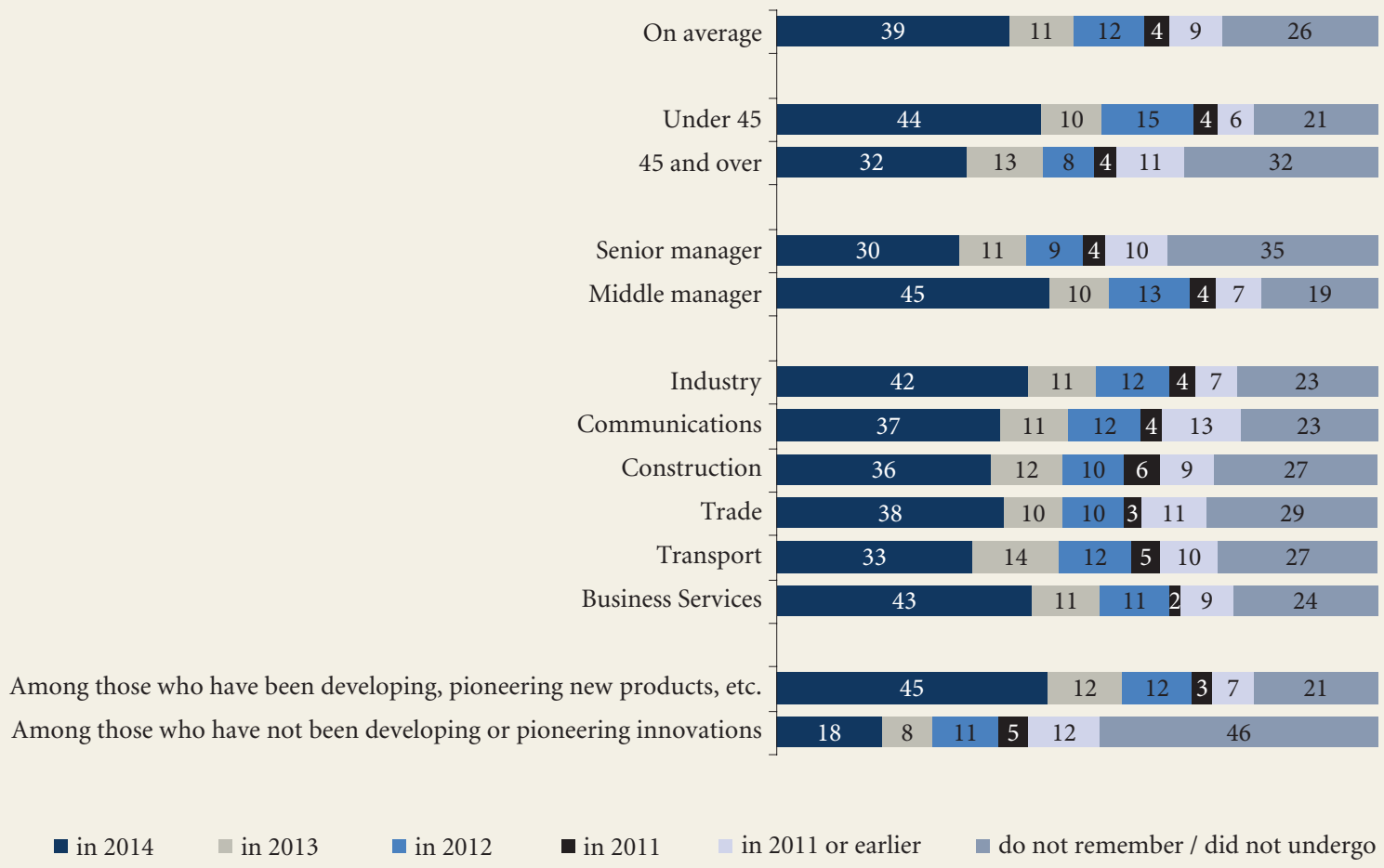

Source: data from the 'Monitoring of Education Markets and Organizations' 2014 employer survey.

When assessing the regularity of training linked to managers' professional activity, surveys recorded that roughly half of all respondents had participated in programmes such as these within the last two years, in 2013 and 2014, and roughly one quarter had been involved within the last four years, i.e. including 2011 and 2012 (Fig. 9). However, more than a quarter of respondents were unable to give or refused to answer the question on when they last raised their qualifications: among top managers this figure was $35 \%$, while heads of departments were more proactive in using their opportunities for additional training. An inter-industry comparison shows roughly comparable regularity of involvement in additional training programmes by members of companies from different industries. The positive correlation between an innovative environment and continuous professional education practices is also corroborated by data on the last time that managers took such a course. $45 \%$ of managers of companies which had developed or introduced new products, technologies, etc. had recently undergone professional training in the year of the survey. Only $18 \%$ of managerial staff engaged in refining their knowledge and skills in more traditional industries.

Changes in the nature of the requirements in terms of employees' professional skills at modern companies are giving rise to demand for updated skills and knowledge both among managers and subordinates. According to employers (including British employers [Kik et al., 2014]), the lower the professional status of an employee, the less likely that he or she will be to satisfy the growing demands of a company. Consequently, low-skilled workers need to involve themselves more actively in lifelong learning programmes, access to which is, as a general rule, difficult. 


\section{Fig. 10. Involvement of workers with various professional statuses in lifelong learning (proportion of respondents aged 25-64 involved in various forms of continuous education in the four weeks preceding the survey, \%)}

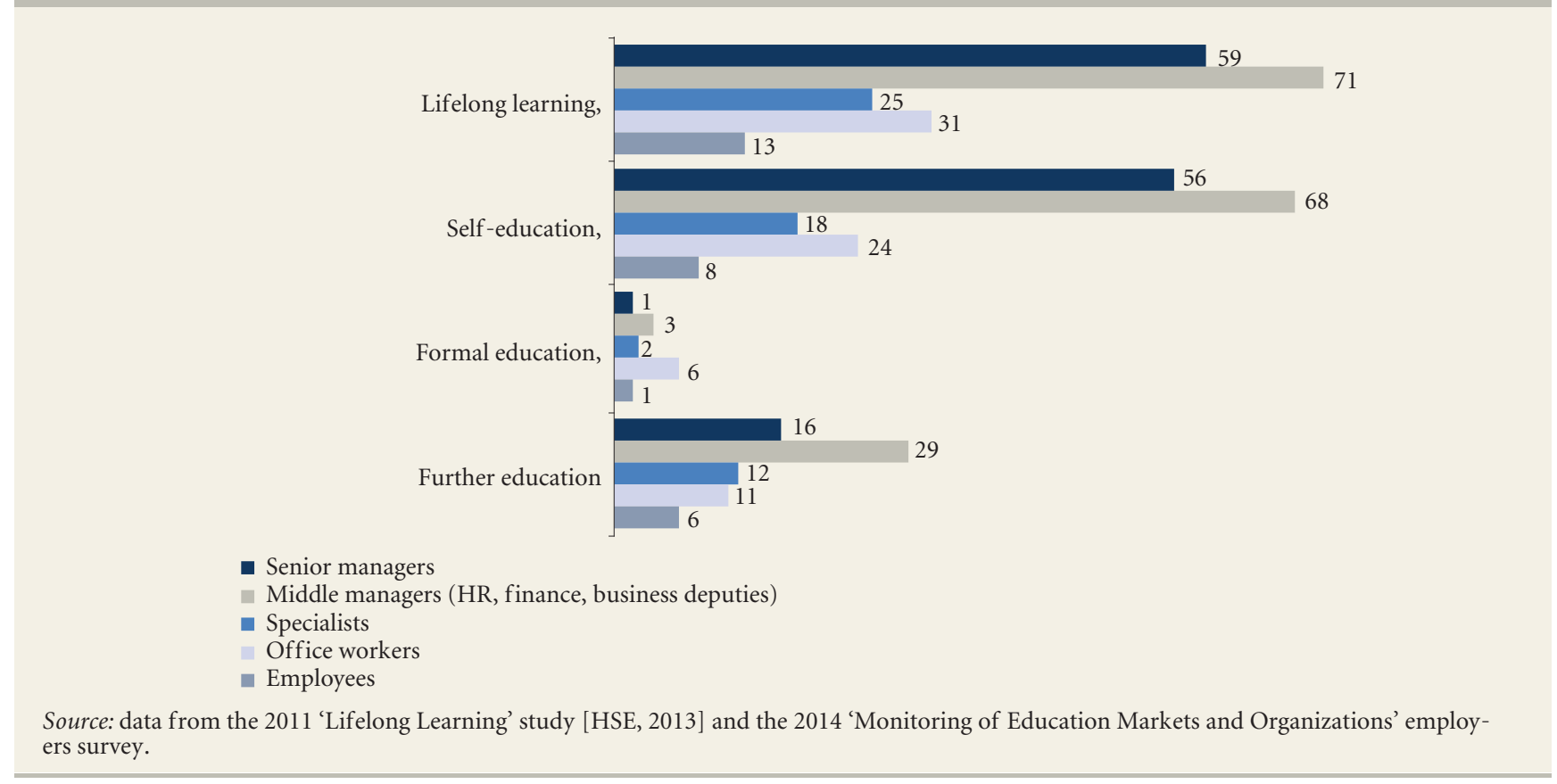

Russian surveys ${ }^{5}$ show a high level of differentiation in the level of involvement in lifelong learning between various levels of management and general workers. The gap between workers and middle and senior managers is particularly high (Fig. 10). In the four weeks preceding the survey, $6 \%$ of skilled workers, almost $30 \%$ of middle managers, and more than $15 \%$ of company managers participated in this type of programme.

The aforementioned inequality in access to lifelong learning between 'gold', 'white' and 'blue collar workers' exists on the European labour market too. A comparison of materials from the Adult Education Survey [Eurostat, 2011] and the pan-Russian 'Lifelong Learning' study [HSE, 2013] shows that the extent of this differentiation is significantly higher in Russia than in leading European countries. In Germany, Switzerland and the Scandinavian countries the gap between workers with a higher education (managers, specialists) and skilled workers in this regard is less than one and a half times, while in Russia it is three times.

Although the proportion of university graduates among Russian company employees is higher than equivalent sectors in the EU, they show less inclination to increase their knowledge and skills through lifelong learning compared with their European counterparts. Eastern Europe lags behind older EU members in this regard, with a few exceptions. In particular, Slovakia has been able to develop effective mechanisms to involve the adult population in lifelong learning: the level of involvement among both managers and specialists as well as skilled workers is higher in Slovakia than the European average (Fig. 11). In Russia, this figure is well below the European average (Fig. 12).

As it turned out, specialists and managers prefer forms of lifelong learning such as conferences, meetings, and seminars, and tend to avoid longer forms of learning such as courses, etc. (Table 4). According to labour market experts [Konovalova, 2008], Russian companies are more attracted to programmes that do not involve prolonged periods of absence for employees from the workplace: one-day events, high intensity mini training sessions or series of short modules, talks by trainers and consultants and corporate conferences, etc. However, ex-

Hereinafter, analysis of Russians' involvement in lifelong learning is based on data from specialist pan-Russian surveys on 'Lifelong Learning', carried out by NRU HSE in conjunction with the Levada Center in 2011-2012, representing the urban and rural adult population in Russia (over 18 years of age) [HSE, 2013]. 
Fig. 11. Involvement of workers with a higher education and skilled workers in lifelong learning by country (proportion of respondents aged 25-64 involved in various forms of continuous education in the four weeks preceding the survey, \%)

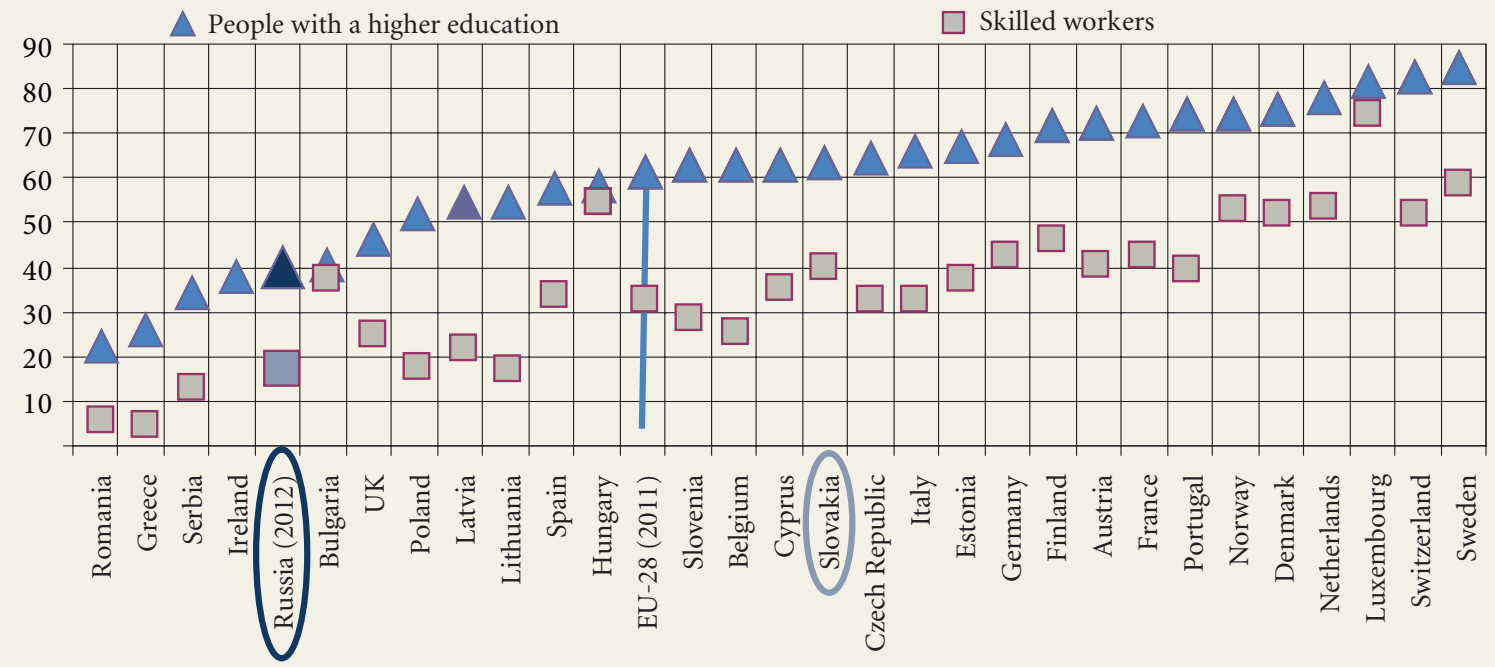

Source: for Russia, data from the 2012 'Lifelong Learning' study [HSE, 2013]; for other countries, the Adult Education Survey 2011 [Eurostat, 2011 ].

perts point out that such forms of education are ineffective in terms of establishing sustainable professional skills among workers, and the vast majority of training companies and consultants consider them incompatible with quality education services.

\section{Involvement of companies in providing lifelong learning to workers}

The aforementioned backwardness of Russian employers compared to European countries in terms of staff training is confirmed by information on key sectors of the economy (Table 5). A similar situation can even be observed in high-tech sectors such as communications and ICT.

An even larger gap can be seen in small business. However, according to existing data [Krasilnikova, Bondarenko, 2014, p. 43], professional training programme activity in companies with staff numbers exceeding 250 people is roughly the same in Russia and the United Kingdom. Slightly more than half of Russian companies employing up to 100 people and $93 \%$ of British firms of the same size have been implementing programmes such as these. A similar statistic for companies with less than 25 workers shows the significant superiority of British companies (77\%) over Russian (almost three times fewer).

Fig. 12. Involvement of various population groups in the corresponding age in Russia and the EU in lifelong learning (for each group, proportion of respondents aged 25-64 involved in various forms of continuous education in the four weeks preceding the survey, \%)

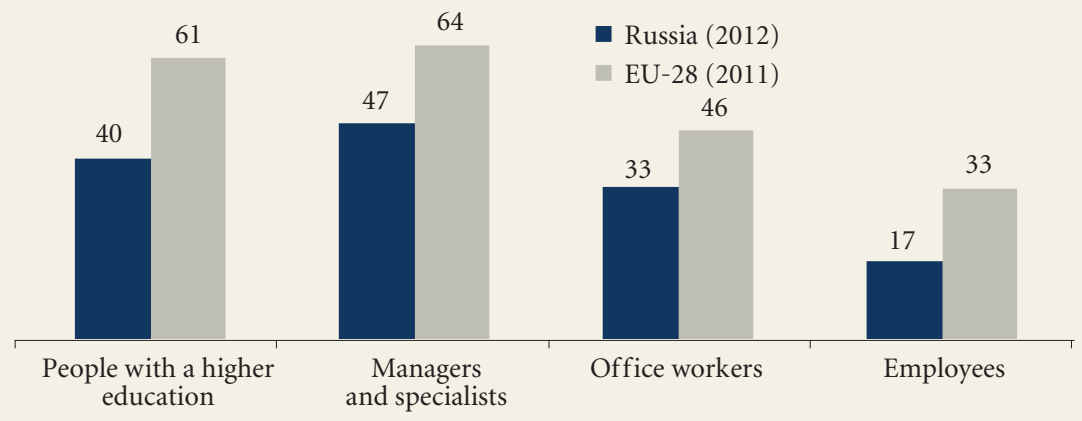

Source: for Russia, data from the 2012 'Lifelong Learning' study [HSE, 2013]; for the EU countries, the Adult Education Survey 2011 [Eurostat, 2011]. 
Table 4. The experience of certain categories of workers in various forms of education over the last 12 months

\begin{tabular}{|c|c|c|}
\hline & \multicolumn{2}{|c|}{$\begin{array}{c}\text { Share of those who participated out } \\
\text { of the total number of employees in } \\
\text { the relevant category }(\%)\end{array}$} \\
\hline & $\begin{array}{l}\text { Regular } \\
\text { personnel }\end{array}$ & $\begin{array}{l}\text { Specialists and } \\
\text { directors }\end{array}$ \\
\hline Number of respondents & 145 & 316 \\
\hline $\begin{array}{l}\text { In regular (weekly, monthly, etc.) or one-time } \\
\text { professional conferences, seminars, training sessions, } \\
\text { meetings for the exchange of experience }\end{array}$ & 8 & 17 \\
\hline $\begin{array}{l}\text { Studying in courses for raising one's qualifications, } \\
\text { courses for the receipt of a new profession }\end{array}$ & 7 & 14 \\
\hline $\begin{array}{l}\text { Studying with the use of a computer, including online } \\
\text { courses }\end{array}$ & 5 & 10 \\
\hline
\end{tabular}

Source: data from the 2012 'Lifelong Learning' study [HSE, 2013].

Companies that are working to modernize their product range, technologies, equipment, work methods, etc. (i.e. are innovation-active) tend to implement the most active staff training policies. They are more likely than other businesses to organize (re)training for employees (up to $76 \%$ of companies), to develop appropriate plans and to contribute to budget spending for this purpose (up to $41 \%$ of companies). However, Russian experts suggest that Russian managers of ten do not have enough information about the situation on the labour market and do not have a detailed description of the skill sets and qualifications of their workers, which reduces the effectiveness of any education initiatives and gives rise to disagreements between company managers and external organizers of training courses [Konovalova, 2008]. According to the 'Monitoring of Education Markets and Organizations' survey for 2014, only 30-40\% of employers providing funding for training for their own employees carried out a systematic assessment of the training needs of their employees (in European countries, this figure is higher than 70\%). Less still, roughly $20-30 \%$, is the proportion of companies that assessed the effectiveness of such programmes and tested workers after they had finished the course (the equivalent European figure is 57\% [Eurostat, 2010]).

The maximum return on investment from manager training comes when 'advanced' knowledge and skills acquired by higher workers are passed on to subordinates and when training processes are synchronized within a company. A similar knowledge exchange mechanism is particularly important in businesses whose activity is linked to innovation (i.e. not based on mass production, but on the project principle). In this case, middle managers (heads of department, team-leaders) act as exchange agents, for whom mentoring or tutoring becomes their prerogative. The role of mentor also requires special training for ordinary employees in a company. Training programmes for line managers are offered in a number of European countries, for example, Germany, France and

\section{Table 5. Company activity in terms of organizing staff training in key industries} in Russia and the European Union (\%)

\begin{tabular}{|c|c|c|c|c|c|c|c|c|}
\hline & \multicolumn{2}{|c|}{ Industry } & \multicolumn{2}{|c|}{ Telecommunications } & \multicolumn{2}{|c|}{ Construction } & \multicolumn{2}{|c|}{ Trade } \\
\hline & $\begin{array}{l}\mathrm{EU}-28 \\
(2010)\end{array}$ & $\begin{array}{l}\text { Russia } \\
(2014)\end{array}$ & $\begin{array}{l}\mathrm{EU}-28 \\
(2010)\end{array}$ & $\begin{array}{l}\text { Russia } \\
(2014)\end{array}$ & $\begin{array}{l}\text { EU-28 } \\
(2010)\end{array}$ & $\begin{array}{l}\text { Russia } \\
(2014)\end{array}$ & $\begin{array}{l}\mathrm{EU}-28 \\
(2010)\end{array}$ & $\begin{array}{l}\text { Russia } \\
(2014)\end{array}$ \\
\hline $\begin{array}{l}\text { Companies that organized employee } \\
\text { training }\end{array}$ & 63 & 67 & 80 & 62 & 64 & 57 & 63 & 42 \\
\hline $\begin{array}{l}\text { Companies that have approved plans } \\
\text { or a budget for employee training }\end{array}$ & 36 & 40 & 53 & 42 & 36 & 28 & 36 & 23 \\
\hline $\begin{array}{l}\text { Companies that have carried out } \\
\text { a systematic analysis of employee } \\
\text { training needs (out of the total } \\
\text { number of companies offering } \\
\text { training) }\end{array}$ & 71 & 40 & 83 & 32 & 71 & 30 & 71 & 30 \\
\hline
\end{tabular}




\section{Table 6. Most significant obstacles and constraints to doing business according to company managers (proportion of respondents selecting the corresponding response as a percentage of the total number surveyed, \%)}

Question to managers: "Select one of the variants to complete this sentence: 'The biggest obstacles to business are linked to...””

\begin{tabular}{|c|c|c|c|c|c|}
\hline & Russia & $\begin{array}{c}\text { New EU } \\
\text { member states }\end{array}$ & $\begin{array}{l}\text { Non-EU } \\
\text { countries in } \\
\text { Eastern Europe }\end{array}$ & $\begin{array}{l}\text { Former USSR } \\
\text { countries } \\
\text { (Europe, } \\
\text { Kazakhstan) }\end{array}$ & $\begin{array}{l}\text { Former USSR } \\
\text { countries } \\
\text { (the Caucasus } \\
\text { and Central Asia) }\end{array}$ \\
\hline $\begin{array}{l}\text {... the quality of the business } \\
\text { environment, the nature of state } \\
\text { regulation (operation of courts, level } \\
\text { of taxes, tax administration, quality of } \\
\text { legislation) }\end{array}$ & 53 & 46 & 40 & 27 & 29 \\
\hline $\begin{array}{l}\text {... access to resources (labour, financial) } \\
\text { and inf rastructure (electricity, land, } \\
\text { roads) }\end{array}$ & 28 & 24 & 25 & 42 & 33 \\
\hline $\begin{array}{l}\text {... a criminal, corrupt, unstable } \\
\text { environment, including political } \\
\text { instability }\end{array}$ & 19 & 31 & 34 & 31 & 38 \\
\hline
\end{tabular}

Source: data from the 2012 and 2013 BEEPS surveys [EBRD, 2014].

Italy as part of Cedefop's ADAPT initiative, and in France FED Construnet, etc. [Janssens, 2001, pp. 63-65]. Corporate training is not built on traditional classbased lessons: knowledge transfer takes place through a mentor ('more guidance, less learning') through mutual learning and the exchange of experience between managers and workers (cross-training). Even the role of organizations providing education services is changing - their task is transforming into a consultancy role for company managers on questions of staff training: developing teaching materials, skills and knowledge transfer techniques, etc. This guarantees a progression from the development of standard mass staff training programmes to individualized solutions ('training workshops').

The prospects of Russian employers further implementing various forms of professional staff training are not in the least affected by the constraints and challenges facing business in the country. According to the results of the 2012 BEEPS survey, the quality of the business environment and the nature of state regulation give rise to the greatest difficulties (Table 6). Even company managers in new EU member countries pointed to these barriers. However, while excessive taxation and limited access to resources (especially, financial resources) of ten cause the most concern among Russian businessmen, in the EU the issues are labour regulation, the functioning of the judicial system and the nature of tax administration.

By the end of 2014, amid the economic crisis, falling rates of production growth and stricter corporate lending requirements of banks, the staff deficit problem and the problem of low levels of qualification took a backseat for Russian companies. In all likelihood, this situation will continue in the short term, and for a large number of businesses, human capital development will not be a priority for investment. Moreover, the reduction in costs will involve the curtailment of already implemented modernization projects, a fact that is confirmed by sociological data: among the key constraints to upgrading technology and equipment and introducing new products and work methods, respondents mentioned general economic instability (29\%) and difficulty in obtaining funding (20\%) [Krasilnikova, Bondarenko, 2014]. Clearly, the cost of additional staff training is an important component of such projects.

Today, such an important (on account of its flexibility) innovative element of the education system as further adult education receives virtually no state funding. With the implementation of anti-crisis measures across the entire country's economy, it would seem extremely pertinent to pay particular attention to partnerships with companies specializing in training and investment in lifelong learning, both of which can provide a positive long-term effect. 


\section{References}

Bennis W., Bene K.D., Chin R. (1961) The planning of change, New York: Holt, Rinehart \& Winston.

BIS (2012) National adult learner survey 2010 (BIS research paper no 63), London: Department for Business, Innovation and Skills.

Blanden J., McNally S. (2015) Reducing inequality in education and skills: Implications for economic growth (EENEE Analytical report no 21), Brussels: European Commission.

Cedefop (2013) Piloting a European employer survey on skill needs illustrative findings (Research paper no 36), Luxembourg: Publications Office of the European Union.

De Broeck V. (2008) Small companies less likely to offer continuing vocational training, Dublin: European Foundation for the Improvement of Living and Working Conditions.

EBRD (2014) Business environment and enterprise performance survey 2012-2013 database. Available at: http://ebrd-beeps. com/data/2012-2013/, accessed 17.02.2015.

European Commission (2004) Eurobarometer 62, Brussels: European Commission.

European Commission (2014) Education and training monitor 2014, Brussels: Directorate-General of Education and Culture.

Eurostat (2005) Statistics in focus. Lifelong learning in Europe (8/2005), Paris: Eurostat.

Eurostat (2010) Continuing Vocational Training Survey (CVTS). Available at: http://ec.europa.eu/eurostat/cache/metadata/ en/trng_cvts_esms.htm, accessed 15.03.2015.

Eurostat (2011) Adult Education Survey database. Available at: http://ec.europa.eu/eurostat/cache/metadata/en/trng_aes_ esms.htm, accessed 17.02.2015.

Eurostat (2015) EU Labour Force Survey results. Available at: http://ec.europa.eu/eurostat/cache/metadata/en/tsdsc440_ esmsip.htm, accessed 17.02.2015.

Gokhberg L., Poliakova V. (2014) Innovative Activities and Skills. The Global Innovation Index 2014. The Human Factor in Innovation, Geneva, Fontainebleau, Ithaca, NY: Cornell University, INSEAD, and WIPO, pp. 93-99.

Healy A., Smith M., Regeczi D., Binda Zane E., Klaassens E., Woodcraft P., Dodd J., Farrar P., Rademaekers K. (2011) Lags in the EU economy's response to change, Rotterdam: ECORYS.

Janssens J. (2001) Innovations in Lifelong Learning: Capitalizing on ADAPT, Luxembourg: Office for Official Publications of the European Communities.

Kik G., Winterbotham M., Vivian D., Shury J., Davies B. (2014) Employer Skills Survey 2013: UK results, London: UK Commission for Employment and Skills.

Konovalova V. (2008) Mirovye tendentsii obutcheniya i razvitiya personala i situatsiya v Rossii [Global Trends staff training and development and the situation in Russia]. Kadrovik. Kadrovyi menedzhment [Personnel. Human Resource Management], no 9. Available at: http://www.case-hr.com/statiyi-i-otcheti/35008.html, accessed 24.03.2015 (in Russian).

Krasil'nikova M., Bondarenko N. (2014) Trebovaniya rabotodatelei k tekushchim i perspektivnym professional'nym kompetentsiyam personala [Requirements for employers to current and prospective staff competency]. Monitoring ekonomiki obrazovaniya. Informatsionnyi byulleten' [Monitoring the Economics of Education. Newsletter], no 1 (75), Moscow: HSE (in Russian).

Krasil'nikova M., Bondarenko N., Kharlamov K. (2005) Spros na rabotchuyu silu - mnenie rabotodatelei [Demand for Workforce - An Employers' Opinion]. Monitoring ekonomiki obrazovaniya. Informatsionnyi byulleten' [Monitoring the Economics of Education. Newsletter], no 1 (19), Moscow: HSE (in Russian).

Manpowergroup (2014) The talent shortage continues. How the ever changing role of HR can bridge the gap (talent shortage survey), Milwaukee, WI: Manpowergroup.

OECD (2014) Education at glance, Paris: OECD.

PEW Research (2013) Higher education, gender and work survey database. Available at: http://www.pewsocialtrends. org/2014/12/22/higher-education-gender-work/, accessed 07.02.2015.

Trubin G. (2011) Innovatsionnaya aktivnost' naseleniya v dopolnitel'nom professional'nom obrazovanii (sotsiologitcheskoe issledovanie Tyumenskoi oblasti) [The innovative activity of the population in the additional professional education (case study of the Tyumen region)]. Professional'noe obrazovanie $v$ Rossii $i$ za rubezhom [Professional education in Russia and abroad], vol. 2, no 4, pp. 61-65 (in Russian).

Verdonschot S. (2009) Learning to innovate. A series of studies to explore and earning in innovation practice, Twente: University of Twente.

West M., Patterson M., Dawson J., Nickell S. (1999) The effectiveness of top management groups in manufacturing organizations, London: London school of Economics and political science. 